\title{
Empirical Evaluation On External Debt Of Malaysia
}

Nor'Aznin Abu Bakar, (Email: noraznin@uum.edu.my), Universiti Utara Malaysia, Malaysia Sallahuddin Hassan, (Email: din636@uum.edu.my), Universiti Utara Malaysia, Malaysia

\begin{abstract}
This study analyzes the effects of external debts on economic growth in Malaysia. The analysis is conducted both at aggregate and disaggregate levels. The empirical results are based on VAR estimates using GDP, external debts, capital accumulation, labor force and human capital. Estimation results at the aggregate level indicate that total external debts affect economic growth positively. In particular, one percentage point increase in total external debts generates 1.29 percentage point of economic growth in the long term. Meanwhile, the positive effects of project loan has been detected at the disaggregate level. However, market loan has not shown any significant effect on economic growth. In the short-run, total external debts as well as project loan has positive effects on economic growth
\end{abstract}

Keywords: Debt, economic growth, time-series model

\section{Introduction}

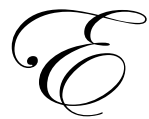

conomic growth is determined by various factors and one of them is debt. Debt or borrowing is vital for financing development, whereby a country borrows to boost long-term productivity and economic output as well as to advance in human development. In this situation, debt is used for growth-related expenditures. Benefits from economic growth and exports will further stimulate the economy and repay lenders the principal and interest owed. However, if a country's debts are disproportionately large as compared to its gross national product (GNP) and export earnings, it will be a problem to a country because instead of stimulating growth and helping to advance human development, debt will deplete economic vitality and drain resources from social sectors. As a result, a country has to divert its resources to repay the high levels of debt i.e. not to default or add arrears to the total debt.

Debt exerts different effects on the economy than taxation. Government will get the debt needed to run its extraordinary expenditures, such as education expenditure and economic expenditures. The economist regards at least some part of education expenditures and economic expenditures as build up human capital and physical capital respectively which can be considered as a source of economic growth. Therefore, debts play a useful role in creation of physical and human capital. However, the national debt was considerably larger proportion of Malaysia's GNP in the 1960s and 1970s than it is today. Perhaps we should recall that all during those years, we had just begun an extensive economic development program under five-years Malaysian Economic Plans. Furthermore, Malaysia is like other developing countries that suffered a heavy burden of debt, particularly during critical worldwide events in the 1970s and 1980s. During these periods, the oil price shock, high interest rates and recessions in the developed countries as well as weak primary commodity prices are usually referred as the major contributors to debt explosion in the developing countries (IMF: 2000). This surge in external debt was accompanied by a debt structural change in responses to the increased risk that accompanied the repayment difficulties that many countries faced.

Although many empirical studies have investigated the relationship between growth and external debt, the results are ambiguous. These results show that there is no consensus on the role of external debt on growth. The economic literature has indicated both direct and indirect channels through which a large foreign debt affects investment and finally negatively output. A leading explanation for this negative relationship is the so-called debtoverhang hypothesis, which states that with the very high levels of debt, the government has no incentives to carry out macroeconomic reforms and policies as the returns of these policies will only be used to repay outstanding debt. 
With such reforms or policies being postponed, incentives for the private sector to invest may also be reduced. Thus it may lead to or even negative levels of economic growth. Foreign debt can also be viewed as a tax, where improvement in the economic performance of the indebted country can be seen increased production and exports that will be received by the creditors.

A problem with the previous studies is that a positive relationship between growth and external debt can exist for different reasons. As growth increases the demand for debt increases too, and it will in turn has a positive effect on debt accumulation. Other things being equal, it is growth that follows debt and not the opposite. The relationship between the external debt burden and economic growth has been examined in this study using VAR framework for the case of Malaysia. Specifically the objectives of the study are; (i) to analyze long run and short run relationship between external debt and economic growth, (ii) to investigate the impact of external debt on Malaysia's economic growth. This study is motivated by the lack of country studies on the external debt-economic growth relationship within the existing literature. There are several concerns with the previous empirical work. Although the nature of relationship between growth and external debt has been rigorously studied, it has not been widely explored in developing countries like Malaysia using the time-series analysis. This study has exposed a new evidence that can be used for policy maker guidance and future study. The paper is organized as follows; section II discusses Malaysia's debt situation. Section III presents the theoretical modeling of economic growth and debt. Data and estimation method are presented in section IV, followed by the empirical results in section V. Section VI provides the conclusions.

\section{Malaysia's Debt Situation}

Beside taxation, debt is another financing alternative of Malaysian government expenditure. The government seeks to borrow because its tax revenues are not sufficient to finance all expenditures that it has budgeted. There are two sources of Malaysia's debt, which are internal debt and external debt. The trend of external debt and domestic debt in Figure 1 demonstrates that the amount of domestic debt has increased while external debt has shown a trend of up and down through out the period. The amount of external debt increased during the period of 1980 - 1986, which can be explained by the economic slump during those years, besides facing a deficit in balance of payment. In 1981 deficit in the balance of payment was RM11,015 million, due to large government spending to finance large industrial projects.

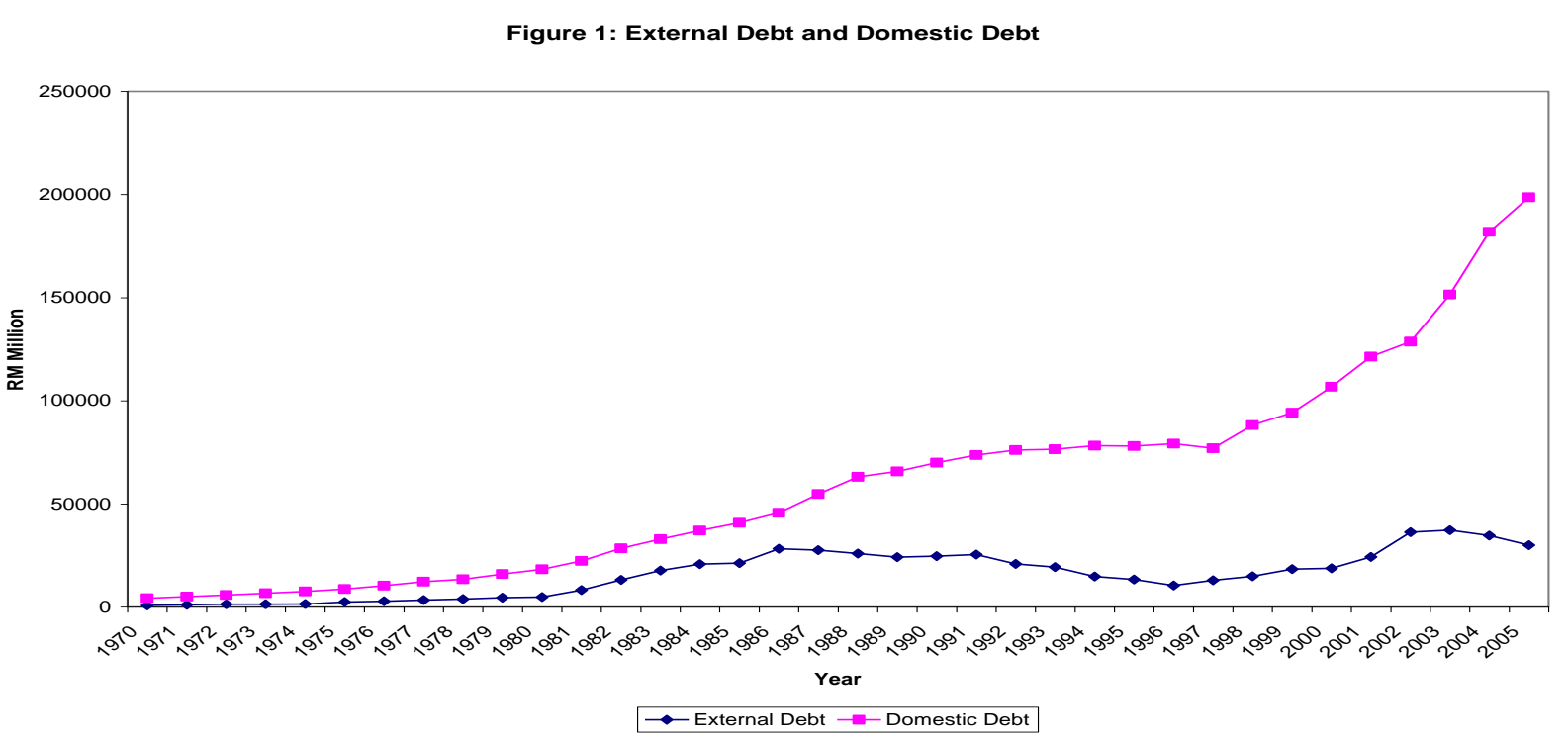

The breakdown of Malaysia's total debt is shown in Table 1. Domestic debt sources are from public sectors, which include state governments, statutory bodies and public enterprises, Employee Provident Fund (EPF), National Savings Bank, Bank Negara, Banking Institutions and Insurance Companies. Meanwhile, the main sources of Malaysian external debt come from the World Bank and Asia Development Bank. The external debt is mainly 
dominated in the US dollar and the balance of the external debt is dominated in various other currencies namely yen, pound sterling, deutschemark, with the yen debt being the second largest component of the external debt.

Table 1: Federal Government Debt (2001-2006)

\begin{tabular}{|c|c|c|c|c|c|c|c|c|c|c|c|c|}
\hline \multirow{2}{*}{$\begin{array}{c}\text { Types of } \\
\text { Debt }\end{array}$} & \multicolumn{6}{|c|}{ RM Million } & \multicolumn{6}{|c|}{ GDP (\%) } \\
\hline & 2001 & 2002 & 2003 & 2004 & 2005 & 2006 & 2001 & 2002 & 2003 & 2004 & 2005 & 2006 \\
\hline $\begin{array}{c}\text { Domestic } \\
\text { Debt }\end{array}$ & 121,396 & 128,680 & 151,483 & 183770 & 198,670 & 217,320 & 36.3 & 36.6 & 38.4 & 41.9 & 40.1 & 39.6 \\
\hline $\begin{array}{c}\text { External } \\
\text { Debt }\end{array}$ & 18,821 & 24,328 & 37,284 & 35499 & 30,000 & 27,054 & 7.3 & 10.6 & 9.5 & 8.1 & 6.1 & 4.9 \\
\hline $\begin{array}{c}\text { Market } \\
\text { Loans }\end{array}$ & 12,041 & 17,682 & 28,189 & 25,695 & 21,169 & 17,805 & 5.3 & 7.7 & 7.2 & 5.9 & 4.3 & 3.2 \\
\hline $\begin{array}{c}\text { Project } \\
\text { Loans }\end{array}$ & 6,780 & 6,646 & 9,095 & 9,804 & 8,831 & 9,249 & 2.0 & 2.9 & 2.3 & 2.2 & 1.8 & 1.7 \\
\hline Total & 145,724 & 167,835 & 188,767 & 219,269 & 228,670 & 244,374 & 43.6 & 47.2 & 47.9 & 50.0 & 46.2 & 44.6 \\
\hline
\end{tabular}

Source: Economic Report 2002/03, 2004/05, 2006/07

Figure 2 illustrates the growth of external debt and internal debt. During the period of 1960s, the growth in Malaysian external debt had been modest compared to other periods. The figure shows that the growth of foreign debt in the 1970s and 1980s is significantly high. The highest peak of external debts was recorded during 1980s. It can be traced to a combination of internal and external factors. For instance, in the 1970s, on the demand side there was a pressing need in oil-importing developing countries for foreign exchange in order to finance balance of payment deficits and public projects following the increase of oil price in the 1970s (Avery, 1990). Along with other domestic factors, such as high trade and budget deficits, low savings rate and poor project selection by donors exacerbated the dependence on external debt. Meanwhile on the supply side, the reversionary conditions in the developed countries forced the international banks to recycle their huge petro-dollar deposits in the developing countries (Bernal, 1987; Afxentiou and Serletis, 1996).

Figure 2: The Growth of External Debt and Domestic Debt

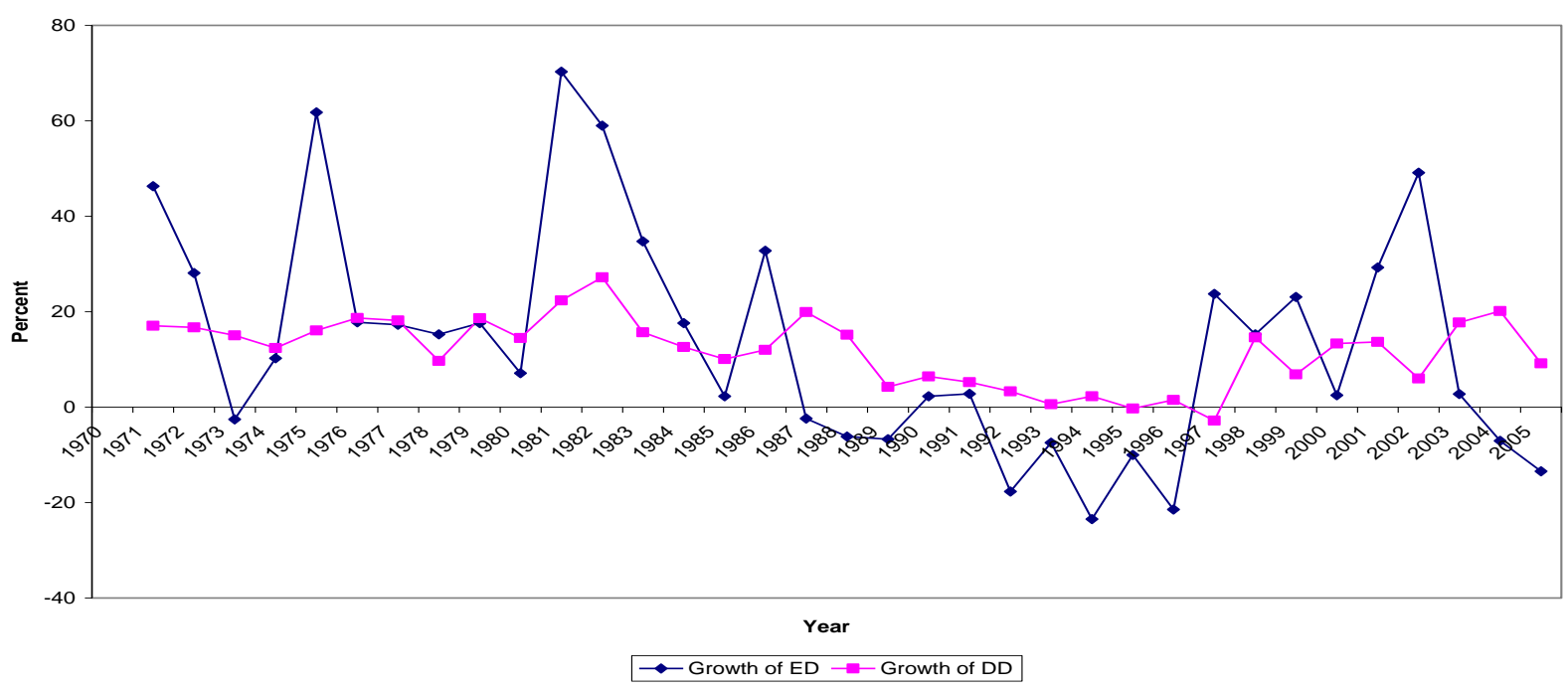

External debt sources can be divided into two types and they are project loans and market loans. Both types of debt are used for different purposes. External project loan is used to finance government's capital expenditure. As shown in Table 1, total external debt in 2006 was RM27,054 million. A major portion of the external debt amounting to about RM17,805 million or 65 percent is made up of market loans. The balance of about RM9,249 million or 35 percent comprises of project loans and supplier credits. Specifically, market loans from the United States was about RM16,553 million (93 percent); from Japan was RM 772 million (4.3 percent) and from the 
United Kingdom was RM480 million (2.7 percent). Market loans comprise of three different instruments of borrowing, which are floating rate notes, syndicated loans and bond issues.

Project loans are obtained from international development financial institutions such as the World Bank and the Asian Development bank and also from bilateral sources. In 2006, the amount of project loans were RM9,249 million, with the amount of RM6,121 million (66 percent) came from bilateral sources and loans from multilateral sources made up the remainder of the project loans - RM3,128 million (34 percent).

\section{Theoretical Modeling of Economic Growth and Debt}

The main focus of this study is to analyze the effects of external debt burden on GNP in Malaysia using the growth accounting framework. The basic model is the output as a function of factor inputs, physical capital (K) and labour (L) as described by Solow (1956). In addition, Romer (1996) point out that human capital (HK) is also important as physical capital and therefore should be included in the model. The human capital consists of abilities, skills and knowledge of particular workers. The Solow's and Romer's models are extended by including external debt, where it is treated as separate inputs in a neoclassical production function.

Thus, the model is shown in equation [1]. The function $F(K, L F, H K, E D)$ exhibits constant returns to scale, positive diminishing returns to inputs, and some positive and smooth elasticity of substitution between the inputs.

[1] $\quad Y=A F(K, L F, H K, E D)$

where $\begin{array}{lll}\mathrm{Y} & = & \text { GNP } \\ \mathrm{A} & = & \text { Index of total factor productivity } \\ \mathrm{K} & = & \text { Capital stock } \\ \mathrm{LF} & = & \text { Labor force } \\ \mathrm{HK} & = & \text { Human capital } \\ \mathrm{ED} & = & \text { External Debt }\end{array}$

By differentiating equation [1], we get equation [2] explain economic growth.

$$
\frac{\dot{Y}}{Y}=F_{K} \frac{K}{Y} \frac{\dot{K}}{K}+F_{L F} \frac{L F}{Y} \frac{\dot{L F}}{L F}+F_{H K} \frac{H K}{Y} \frac{\dot{H K}}{H K}+F_{D S} \frac{E D}{Y} \frac{\dot{E D}}{E D}+\frac{\dot{A}}{A}
$$

If the factors of production are rewarded by their marginal product, then $F_{K} \frac{K}{Y}, F_{L} \frac{L F}{Y}, F_{H K} \frac{H K}{Y}$ and $F_{D S} \frac{E D}{Y}$ are the share of profits, the share of labour, the share of human capital, and the share of debt services, respectively. With a homothetic production function, these shares sum to one. Hence, if we denote $F_{K} \frac{K}{Y}=\alpha$ and $F_{L} \frac{L F}{Y}=\beta, F_{L} \frac{H K}{Y}=\delta$ then $F_{D S} \frac{E D}{Y}=1-\alpha-\beta-\delta$. Thus equation [2] become

$$
\begin{aligned}
& \frac{\dot{Y}}{Y}=\alpha \frac{\dot{K}}{K}+\beta \frac{\dot{L F}}{L F}+\delta \frac{\dot{H K}}{H K}+(1-\alpha-\beta-\delta) \frac{\dot{E D}}{E D}+\frac{\dot{A}}{A} \\
& \frac{\dot{Y}}{Y}=\alpha \frac{\dot{K}}{K}+\beta \frac{\dot{L F}}{L F}+\delta \frac{\dot{H K}}{H K}+\theta \frac{\dot{E D}}{E D}+\frac{\dot{A}}{A} \\
& \text { where, } 0<\alpha<1,0<\beta<1,0<\delta<0 \text { and } 0<\theta<0
\end{aligned}
$$

If $\frac{\dot{Y}}{Y}=y, \frac{\dot{K}}{K}=k, \frac{\dot{L F}}{L F}=l f, \frac{\dot{H K}}{H K}=h k, \frac{\dot{E D}}{E D}=d s$ and $\frac{\dot{A}}{A}=a$, thus equation [2.4] can be shown by equation [5]. 


$\begin{array}{lll}\text { where } & = & \text { output growth rate } \\ k & = & \text { capital stock growth rate } \\ \text { lf } & = & \text { labor force growth rate } \\ h k & = & \text { human capital growth rate } \\ \text { ed } & = & \text { external dedbt growth rate }\end{array}$

As stated by Cunnigham (1993), the debt burden can be considered as debate in the production function due to its effects on the productivity of labor and capital in a similar manner to the inclusion of export in the production function. The need to service a country's debt will affect how labor and capital will be employed in the production function. Specifically, if the benefits of the production increase go to foreign creditors and not domestic agents, little motivation is given to increase the productivity of capital or labor; therefore an increase in debt burden will decrease economic growth. However, the model used by Cunningham (1993) assumes that the production function only consists of physical capital and labor. When a country has a substantial debt burden, the way which labor and capital will be exploited in the production process is bound to be influenced by the need to service debt. Specifically, if the increase in productivity gives more benefit to foreign creditors rather than domestic agents, the latter are discouraged from increasing capital or labor.

\section{Methodology}

\section{Model Specification}

The analytical framework developed in Section III provides theoretical motivation for the existence of growth and external debt linkage. It also has some testable implications worth investing on empirical grounds. Hence, to estimate equation [5], we proceed with the empirical specification shown by equation [6].

$$
\mathrm{LY}=\alpha_{0}+\alpha_{1} \mathrm{LK}+\alpha_{2} \mathrm{LLF}+\alpha_{3} \mathrm{LHK}+\alpha_{4} \mathrm{LED}+\varepsilon
$$

where LY denotes natural log of economic growth, LK the natural log of capital stock, LLF the natural log of labor force, LHK the natural log of human capital, and LED the natural log external debt.

Since ED is disaggregated into two categories, market loan (ML) and project loan (PL), the empirical specification are shown by equation [7] and [8]. ML and PL are also in natural log.

$$
\begin{aligned}
& \mathrm{LY}=\alpha_{0}+\alpha_{1} \mathrm{LK}+\alpha_{2} \mathrm{LLF}+\alpha_{3} \mathrm{LHK}+\alpha_{4} \mathrm{LML}+\varepsilon \\
& \mathrm{LY}=\alpha_{0}+\alpha_{1} \mathrm{LK}+\alpha_{2} \mathrm{LLF}+\alpha_{3} \mathrm{LHK}+\alpha_{4} \mathrm{LPL}+\varepsilon
\end{aligned}
$$

The capital stock is defined as the values of the existing supply of physical goods that are used in the production process i.e. buildings, machinery, equipment and inventory. As stated by Ghali (1998), the capital stock is important not only as a component of final aggregate demand but also in terms of the impact of capital stock on the economy's growth and employment. $\alpha_{1}$ is expected to have a positive coefficient. The labor force is defined as the employed labor force. Since the rate of utilization of the labor force is important in production, employed labor force is used rather than the full labor force. $\alpha_{2}$ is expected to be positive. The human capital is described, as the knowledge and skills embodied in individuals and it is an important source of economic growth. Human capital accumulation is believed to promote higher growth by improving labor force, which will be more productive on the job, by requiring less supervision and processing greater initiative in handling job-related problems. It can be proxied by government education expenditures (see Gungor, 1997). The external debt is expected to have negative effect on economic growth. When a country has a large debt burden the manner in which labor and capital will be exploited in the production process is bound to be influenced by the need to service that debt. (see Rockerbie, 1996; Afxentious, 1993; and Cunningham1993). For empirical purposes, external debt service is decomposed into two measures, market loan and project loan. 
The secondary time series data for the period of 1970-2005 are used through out the study. They are gathered and verified from various sources, i.e. International Financial Statistics by International Monetary Fund (IMF), Bank Negara Malaysia and Malaysian Department of Statistics.

\section{Method Of Analysis}

This study is conducted both at the aggregate and disaggregate levels. A Vector Autoregression (VAR) analysis, which was introduced by Sims (1980), is used to estimate and to evaluate the effect of external debts on economic growth. The VAR approach is chosen because it has become a more usual tool and one of the principal tools of macroeconometric analysis, as it allows for the endogeneity of both external debts and growth including dynamic effects between the variables. The approach has a number of advantages over Ordinary Least Square (OLS) method such as the VAR approach does not impose any causal links between the variables a priori, allows for indirect links between the variables, and does not assume that there is at most one long-run (cointegration) relationship among the variables in the model.

We employed a VAR model of the form shown by equation [9]

$$
Y_{t}=A(L) Y_{t-1}+\mu+\varepsilon_{t}
$$

where $Y_{t}$ is a vector of endogenous variables, $\mu$ is a vector of constant terms and $\varepsilon_{t}$ is a vector of error terms, $\varepsilon_{\mathrm{t}} \equiv\left[\varepsilon_{1 \mathrm{t}}, \ldots, \varepsilon_{\mathrm{kt}}\right]^{\prime}$ that are assumed to be white noise, i.e. $\mathrm{E}\left[\varepsilon_{t}\right]^{\prime}=0^{\prime}, \mathrm{E}\left[\varepsilon_{t} \varepsilon_{t}^{\prime}\right]=\Omega^{\prime}$, and $\mathrm{E}\left[\varepsilon_{t} \varepsilon_{s}^{\prime}\right]=0^{\prime}$ for $s^{\prime} \neq t^{\prime}$, with $\Omega^{\prime}$ a $(k \times k)^{\prime}$ symmetric positive definite matrix. The vector $\mathrm{Y}_{\mathrm{t}}$ comprises the variables $Y_{t}=\left(G D P_{t}, K_{t}, L F_{t}, H_{t}, E D_{t}\right)$, where GDP stands for real output, $K$ for capital stock, HK for human capital and ED for external debt.

\section{Empirical Results}

\section{Unit Root Tests}

The graphical analysis of the previous section suggests that all series entering the model are non-stationary. To empirically prove non-stationary, the unit root test is performed. The results for unit root tests are shown in Table 2. The null hypothesis of no stationary is not rejected in any case; either with a constant and trend is included in the estimation, in level at conventional levels of statistical significance. They imply that all series exhibit nonstationary in levels. However, when the series are first differenced, the no stationary hypothesis is dismissed in almost all cases, as can be inferred from Table 2. This suggests that these series are integrated of order one i.e., I (1). As to the optimal number of lags, the AIC and SIC suggest choosing 2 lags, or $\mathrm{k}=2$ for the level VAR Misspecification tests for residual autocorrelation, normality and heteroscedasticity indicate that the model is well specified.

\section{Cointegration Analysis}

The results of unrestricted cointegration rank tests presented in Table 3 could reject the null hypothesis of no cointegration at the five per cent confidence level. Focusing on the $\lambda_{\max }$ and the $\lambda_{\text {trace }}$, both the statistics show evidence consistent with the presence of two cointegration vector since the null hypothesis of no cointegration $(r=$ 0 ) can be rejected in each of the three cases. For example, for model A, the calculated $\lambda_{\max }$ statistic of 51.062 is larger than its critical value of 37.164. Therefore, these results, like those of model A through $\mathrm{C}$, indicate the presence of a long-run equilibrium among external debt, market loan, project loan and economic growth or they have permanent effects on economic growth. 
Table 2: ADF Unit Root Tests

\begin{tabular}{|c|c|c|c|c|}
\hline \multirow[t]{2}{*}{ Variables } & \multicolumn{2}{|c|}{ Level } & \multicolumn{2}{|c|}{ First Difference } \\
\hline & Lags Included & ADF Statistics & Lags Included & ADF Statistics \\
\hline \multicolumn{5}{|c|}{ Trend and constant are not included in the regression } \\
\hline GDP & 0 & 1.637 & 0 & $-5.124 * *$ \\
\hline ED & 1 & -0.365 & 0 & $-3.351 * *$ \\
\hline ML & 1 & -0.651 & 0 & $-3.481 * *$ \\
\hline PL & 0 & 1.239 & 0 & $-4.074 * *$ \\
\hline $\mathrm{LF}$ & 5 & 1.475 & 6 & $2.075 * *$ \\
\hline $\mathrm{K}$ & 0 & 0.568 & 0 & $-4.925 * *$ \\
\hline $\mathrm{HK}$ & 9 & 2.069 & 7 & $2.873 * *$ \\
\hline \multicolumn{5}{|c|}{ Constant is included in the regression } \\
\hline GDP & 0 & -0.146 & 0 & $-5.744 * *$ \\
\hline ED & 6 & -1.579 & 0 & $-3.402 * *$ \\
\hline ML & 1 & -1.858 & 0 & $-3.494 * *$ \\
\hline PL & 0 & -1.087 & 0 & $-4.409 * *$ \\
\hline $\mathrm{LF}$ & 2 & 2.514 & 1 & $-5.525 * *$ \\
\hline $\mathrm{K}$ & 0 & -0.743 & 0 & $-5.101 * *$ \\
\hline $\mathrm{HK}$ & 9 & 1.864 & 7 & $-6.999 * *$ \\
\hline \multicolumn{5}{|c|}{ Trend and constant are included in the regression } \\
\hline GDP & 0 & -2.509 & 9 & $-4.069 *$ \\
\hline ED & 5 & -3.346 & 9 & $-3.593 * *$ \\
\hline ML & 1 & -2.492 & 0 & $-3.409 * * *$ \\
\hline PL & 1 & -1.778 & 0 & $-4.368 * *$ \\
\hline LF & 2 & -0.959 & 1 & $-6.536 * *$ \\
\hline $\mathrm{K}$ & 0 & -2.154 & 9 & $-4.657 * *$ \\
\hline HK & 4 & 3.001 & 1 & $-7.900 * *$ \\
\hline
\end{tabular}

Table 3: Johansen Cointegration Tests

\begin{tabular}{|c|c|c|c|c|c|}
\hline $\begin{array}{c}\text { Number of } \\
\text { cointegrating } \\
\text { vector }(r)\end{array}$ & Eigenvalue & $\begin{array}{c}\text { Trace Test } \\
\left(\lambda_{\text {trace }}\right)\end{array}$ & $\begin{array}{c}\text { Critical Value } \\
(5 \%)\end{array}$ & $\begin{array}{c}\text { Maximum } \\
\text { Eigenvalue Test } \\
\left(\lambda_{\max }\right)\end{array}$ & $\begin{array}{c}\text { Critical Value } \\
(5 \%)\end{array}$ \\
\hline \multicolumn{6}{|c|}{ i) Model A: Aggregate External Debt } \\
\hline None $*$ & 0.787 & 111.206 & 79.341 & 51.062 & 37.164 \\
\hline At most $1 *$ & 0.611 & 60.145 & 55.246 & 31.145 & 30.815 \\
\hline At most 2 & 0.409 & 28.999 & 35.011 & 17.399 & 24.252 \\
\hline At most 3 & 0.266 & 11.599 & 18.398 & 10.201 & 17.148 \\
\hline At most 4 & 0.041 & 1.399 & 3.841 & 1.399 & 3.841 \\
\hline \multicolumn{6}{|c|}{ ii) Model B: Market Loan } \\
\hline None $*$ & 0.802 & 114.143 & 79.341 & 53.498 & 37.164 \\
\hline At most $1 *$ & 0.599 & 60.645 & 55.246 & 30.139 & 30.815 \\
\hline At most 2 & 0.431 & 30.506 & 35.011 & 18.627 & 24.252 \\
\hline At most 3 & 0.262 & 11.878 & 18.398 & 10.014 & 17.148 \\
\hline At most 4 & 0.055 & 1.864 & 3.841 & 1.864 & 3.841 \\
\hline \multicolumn{6}{|c|}{ iii) Model C: Project Loan } \\
\hline None $*$ & 0.768 & 106.981 & 79.341 & 48.200 & 37.164 \\
\hline At most $1 *$ & 0.565 & 58.780 & 55.246 & 27.487 & 30.815 \\
\hline At most 2 & 0.334 & 31.293 & 35.011 & 13.391 & 24.252 \\
\hline At most 3 & 0.297 & 17.903 & 18.398 & 11.646 & 17.148 \\
\hline At most 4 & 0.173 & 6.257 & 3.841 & 6.257 & 3.841 \\
\hline
\end{tabular}

Maximum Eigenvalue and Trace tests indicate 2 cointegrating equationn(s) at the 0.05 level

* denotes rejection of the hypothesis at the 0.05 level

**MacKinnon-Haug-Michelis (1999) p-values 
Subsequently, we proceeded to estimate long-run relationship between growth and external debts, market loan and project loan. The long-run relationships have been estimated by estimating cointegrating vector parameters. By imposing two cointegration relationship yielded aggregate and disaggregate results shown by equation [15]. The estimated coefficient for debt is highly significantly different from zero, which suggests that a long-run cointegration relationship exists.

i) Aggregate Estimation:

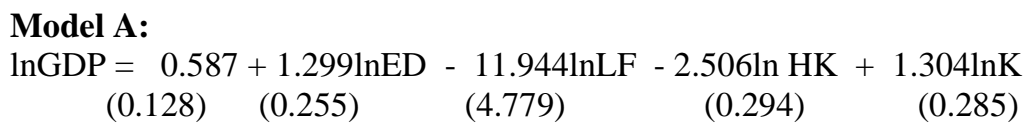

ii) Disaggregate Estimation:

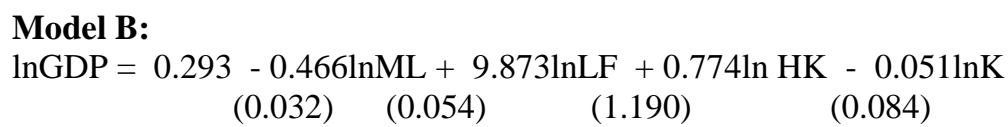

Model C:

$\operatorname{lnGDP}=0.293-0.236 \operatorname{lnPL}+7.125 \operatorname{lnLF}-0.274 \ln \mathrm{HK}+0.422 \operatorname{lnK}$

The estimation results for aggregate and disaggregate approaches appear to be rather similar in the case of estimated coefficients. Aggregate estimation yields a much higher estimate and correct sign of the coefficient of external debts.

\section{Error Correction Model}

Before estimating ECM, we determine the appropriate lag. Since, the AIC suggests an optimal number of two lags, or $k=2$, for the level VAR and we thus use two lags, or $\mathrm{k}=2$, for the estimation of ECM in equation [7]. The results for aggregate analysis are shown in Table 4.

Table 4: Estimated Short-Run Relationship

\begin{tabular}{|c|c|c|c|}
\hline Variables & Coefficients & Standard Errors & t-values \\
\hline Constant & 0.067 & 0.088 & 0.761 \\
ECT & -0.922 & 0.333 & $-2.769^{*}$ \\
D(LNGDP(-1)) & -1.949 & 0.786 & $-2.262^{*}$ \\
D(LNGDP(-2)) & -1.687 & 0.744 & $2.181^{*}$ \\
D(LNED(-1)) & 0.146 & 0.067 & 1.379 \\
D(LNED(-2)) & 0.229 & 0.166 & 1.842 \\
D(LNLF(-1)) & 3.538 & 1.921 & $2.442^{*}$ \\
D(LNLF (-2)) & 4.600 & 1.884 & -0.368 \\
D(LNHK(-1)) & -0.053 & 0.145 & $-2.063^{*}$ \\
D(LNHK (-2)) & -0.032 & 0.015 & $3.088^{*}$ \\
D(LNK (-1)) & 0.038 & 0.030 & $5.035^{*}$ \\
D(LNK (-2)) & 0.052 & 0.010 & \\
\hline R-squared & 0.779 & & \\
F-statistic & 3.741 & & \\
Akaike AIC & -1.116 & & \\
Schwarz SC & -0.571 & & \\
\hline
\end{tabular}

$*$ denotes rejection of the hypothesis at the 0.05 level

The estimated value of ECT is -0.922 and it is highly significantly different from zero, indicating the speed of adjustment of growth to the long-run equilibrium. The result confirms the existence of a long-term growth-debt cointegration relationship and that short run is driven by the extent of the gap between current and long run 

equilibrium value. The coefficients of external debts for both lags have the expected signs and highly significantly different from zero which are consistent with the theory. Meanwhile the disaggregate analysis is shown in Table 5 and Table 6. These findings, either for the long run or short-run similar to past researches which have found that debt is significant in explaining growth.

Table 5: Estimated Short-Run Relationship

\begin{tabular}{|c|c|c|c|}
\hline \multicolumn{3}{|c|}{ Market Loan (ML): } & t-values \\
\hline Variables & Coefficients & Standard Errors & 0.895 \\
Constant & 0.075 & 0.084 & $-2.129^{*}$ \\
ECT & -0.089 & 0.042 & $-2.425^{*}$ \\
D(LNGDP(-1)) & -2.825 & 1.165 & -1.386 \\
D(LNGDP(-2)) & -0.849 & 0.613 & -0.967 \\
D(LNML(-1)) & -0.140 & 0.145 & 0.486 \\
D(LNML(-2)) & 0.056 & 0.116 & 1.634 \\
D(LNLF (-1)) & 4.667 & 2.857 & $2.090^{*}$ \\
D(LNLF (-2)) & 6.039 & 2.889 & -0.688 \\
D(LNHK (-1)) & -0.097 & 0.140 & 0.111 \\
D(LNHK (-2)) & 0.015 & 0.136 & 0.717 \\
D(LNK (-1)) & 0.316 & 0.441 & 1.604 \\
D(LNK (-2)) & 0.448 & 0.279 & \\
R-squared & 0.608 & & \\
F-statistic & 0.502 & & \\
Akaike AIC & -1.021 & & \\
Schwarz SC & -0.477 & & \\
\hline
\end{tabular}

* denotes rejection of the hypothesis at the 0.05 level

Table 6: Estimated Short-Run Relationship

\begin{tabular}{|c|c|c|c|}
\hline \multicolumn{3}{|c|}{ Project Loan (PL): } \\
\hline Variables & Coefficients & Standard Errors & t-values \\
\hline Constant & -0.004 & 0.076 & -0.054 \\
ECT & -0.313 & 0.259 & -1.203 \\
D(LNGDP(-1)) & 0.326 & 0.504 & 0.647 \\
D(LNGDP(-2)) & -0.234 & 0.374 & -0.626 \\
D(LNPL(-1)) & -0.061 & 0.194 & -0.313 \\
D(LNPL(-2)) & 0.912 & 0.221 & $-0.984^{*}$ \\
D(LNLF (-1)) & -1.204 & 1.227 & -0.899 \\
D(LNLF (-2)) & -1.044 & 1.161 & 1.290 \\
D(LNHK (-1)) & 0.147 & 0.114 & $-2.031^{*}$ \\
D(LNHK (-2)) & -0.172 & 0.085 & 0.167 \\
D(LNK (-1)) & 0.050 & 0.299 & $3.244^{*}$ \\
D(LNK(-2)) & 0.085 & 0.026 & \\
R-squared & 0.622 & & \\
F-statistic & 3.142 & & \\
Akaike AIC & -1.761 & & \\
Schwarz SC & -1.216 & & \\
\hline
\end{tabular}

* denotes rejection of the hypothesis at the 0.05 level

\section{Impulse Response}

Figure 4, Figure 5 and Figure 6 display impulse responses functions (IRFs) of growth to external debts shock, market loan, and project loan respectively which are reflected by a one-standard-deviation shock. The vertical axes measure the cumulative effects on growth (percentage changes in growth) due to a one per cent unexpected increase in external debt, market loan and project loan. 
i) Response of LNGDP to LNED

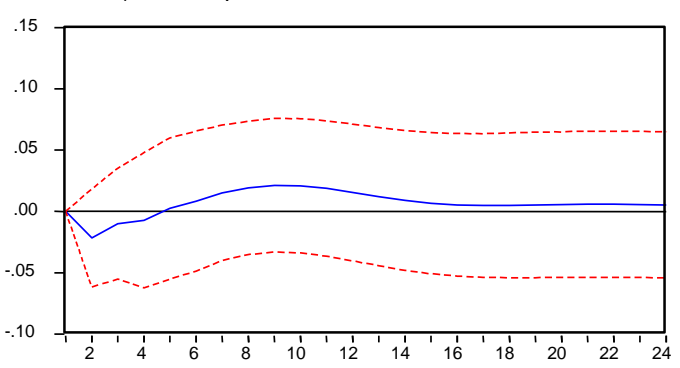

iii) Response of LNGDP to LNHK

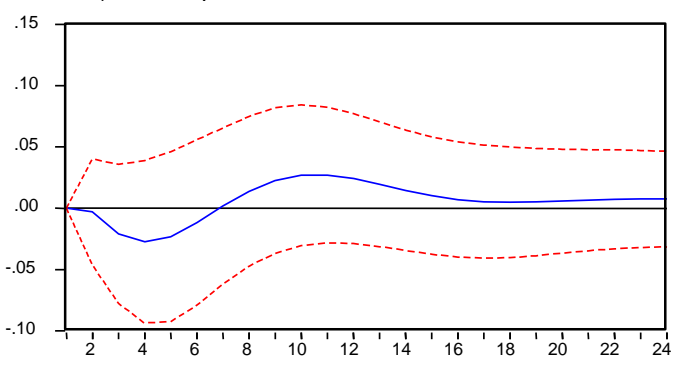

ii) Response of LNGDP to LNLF

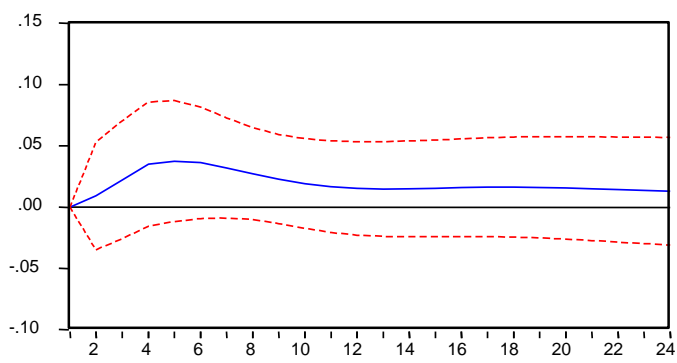

iv) Response of LNGDP to LNCF

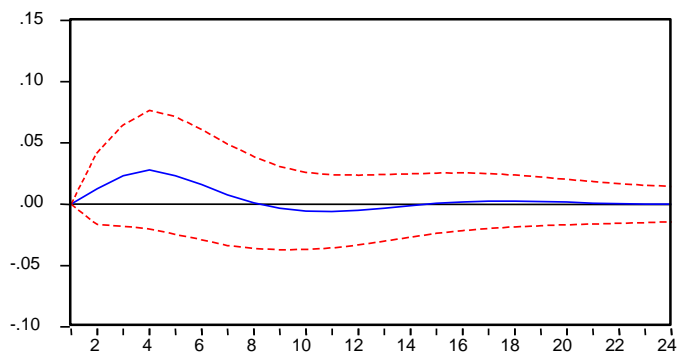

Response to Cholesky One S.D. Innovation \pm 2 S.E.

Figure 4: Impulse Response of Growth to External Debt, Employment, Education and Capital Formation

i) Response of LNGDP to LNM L

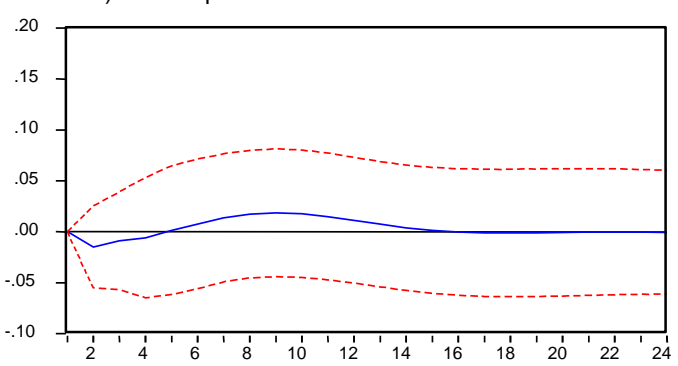

iii) Response of LNGDP to LNHK

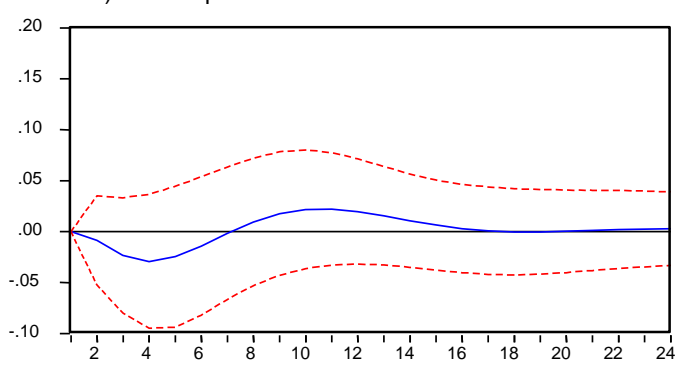

ii) Response of LNGDP to LNLF

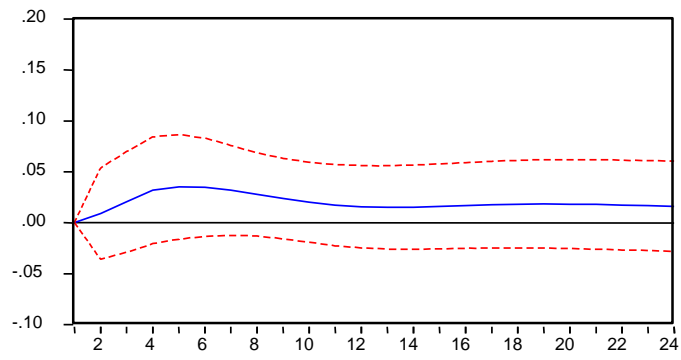

iv) Response of LNGDP to LNCF

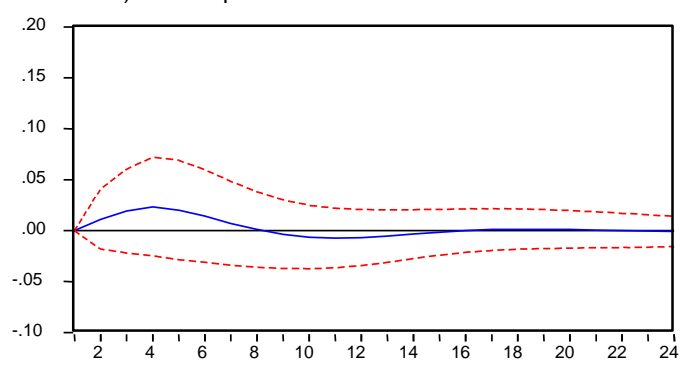

Response to Cholesky One S.D. Innovation \pm 2 S.E.

Figure 5: Impulse Response of Growth to Market Loan, Employment, Education and Capital Formation 

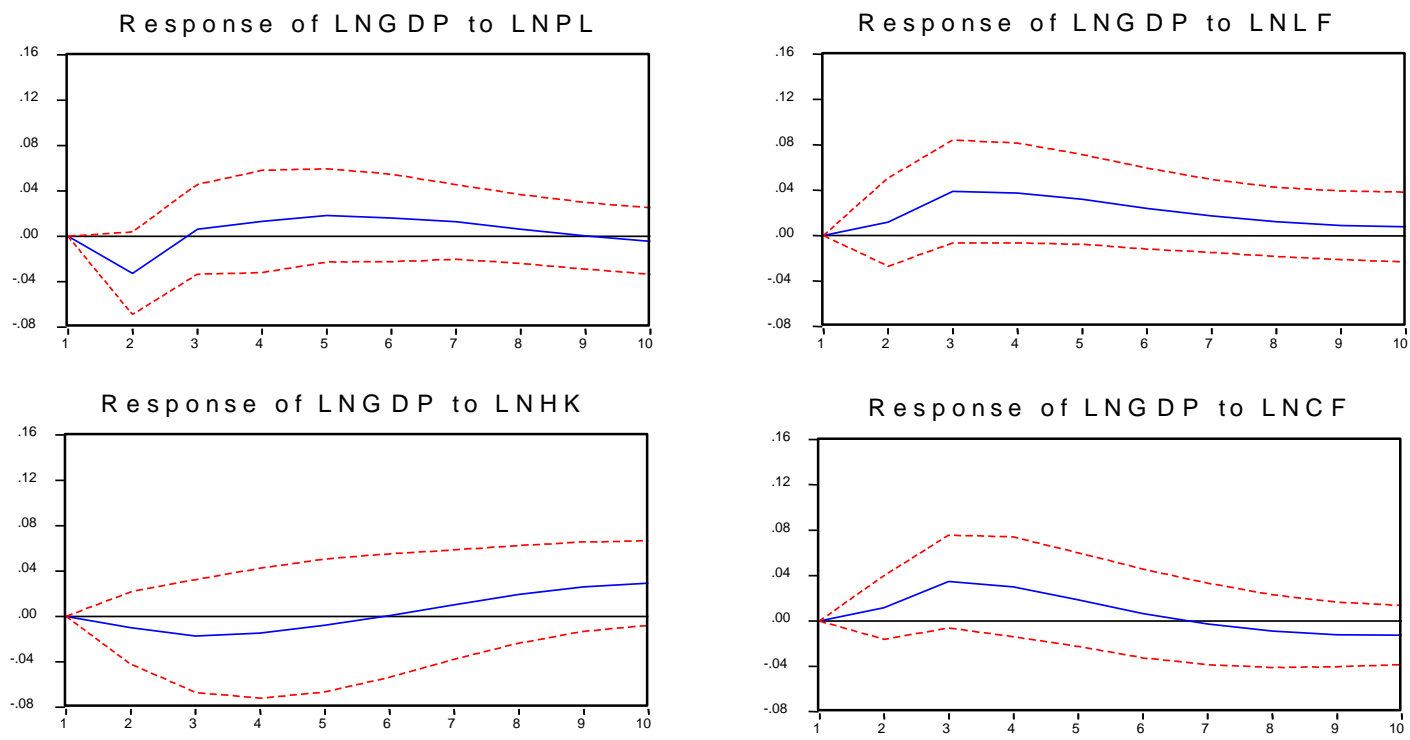

Response to Cholesky One S.D. Innovation \pm 2 S.E.

Figure 6: Impulse Response of Growth to Project Loan, Employment, Education and Capital Formation Notes: Solid lines are point estimate of the impulse response, and dashed line represents one-standard-deviation bands.

These figures show that at most horizons (including the 24-month horizon), the IRFs of the economic growth to a external debts shock. So, in addition to its own shocks, economic growth responds significantly to shock in external debts and other variables. As expected, the results support the argument that there is response of the economic growth to a external debts shock. The figure illustrates that economic growth reacts negatively at the beginning, particularly before year four and positively to external debts at long horizon. It also has a positive response to shock of other variables. External debts shock has a permanent impact on the economic growth.

\section{Variance Decomposition}

Table 7, Table 8 and Table 9 report the FEDVs of the economic growth to external debt, market loan and project loan shock. In model A (Table 7), for instance, a year after impact, the shock can significantly explain only 2.2 per cent of fluctuations in the economic growth. Therefore, the debt transitory shock can be considered as a minor driving force of the economic growth in the short run. A striking fact revealed by the FEVDs is that, even in the long run, the other variables transitory shock dominated fluctuations in the economic growth. The table shows that, for the three models, 12 year after impacts, an external debt, market loan and project loan shocks can explain almost $3.5-6.5$ percent of fluctuation in the economic growth. Other shocks have more importance effect over the period under consideration.

Table 7: Forecast Error Variance Decomposition of LNGDP (LNED)

\begin{tabular}{ccccccc}
\hline Period & S.E. & LNGDP & LNED & LNLF & LNHK & LNK \\
\hline 1 & 0.109 & 100.000 & 0.000 & 0.000 & 0.000 & 0.000 \\
2 & 0.146 & 96.606 & 2.204 & 0.389 & 0.043 & 0.758 \\
3 & 0.169 & 91.919 & 2.020 & 2.017 & 1.581 & 2.463 \\
4 & 0.183 & 84.746 & 1.868 & 5.357 & 3.581 & 4.448 \\
5 & 0.193 & 79.526 & 1.701 & 8.603 & 4.691 & 5.479 \\
6 & 0.199 & 76.215 & 1.777 & 11.429 & 4.771 & 5.808 \\
7 & 0.202 & 73.961 & 2.263 & 13.456 & 4.593 & 5.728 \\
8 & 0.206 & 71.857 & 3.037 & 14.707 & 4.875 & 5.524 \\
9 & 0.211 & 69.661 & 3.933 & 15.267 & 5.816 & 5.324 \\
10 & 0.215 & 67.642 & 4.693 & 15.391 & 7.114 & 5.159 \\
11 & 0.219 & 66.135 & 5.211 & 15.314 & 8.322 & 5.017 \\
12 & 0.224 & 65.258 & 5.485 & 15.207 & 9.169 & 4.879 \\
\hline
\end{tabular}


Table 8: Forecast Error Variance Decomposition of LNGDP (LNML)

\begin{tabular}{ccccccc}
\hline Period & S.E. & LNGDP & LNML & LNLF & LNHK & LNK \\
\hline 1 & 0.113 & 100.000 & 0.000 & 0.000 & 0.000 & 0.000 \\
2 & 0.151 & 97.803 & 0.966 & 0.359 & 0.322 & 0.549 \\
3 & 0.174 & 93.703 & 0.987 & 1.647 & 2.031 & 1.632 \\
4 & 0.189 & 87.795 & 0.933 & 4.237 & 4.111 & 2.925 \\
5 & 0.199 & 83.288 & 0.849 & 6.947 & 5.250 & 3.666 \\
6 & 0.205 & 80.283 & 0.939 & 9.433 & 5.413 & 3.931 \\
7 & 0.209 & 78.213 & 1.324 & 11.365 & 5.205 & 3.893 \\
8 & 0.213 & 76.399 & 1.933 & 12.679 & 5.228 & 3.761 \\
9 & 0.217 & 74.630 & 2.603 & 13.410 & 5.704 & 3.653 \\
10 & 0.221 & 73.060 & 3.144 & 13.732 & 6.465 & 3.599 \\
11 & 0.225 & 71.920 & 3.471 & 13.828 & 7.204 & 3.577 \\
12 & 0.229 & 71.295 & 3.598 & 13.847 & 7.711 & 3.549 \\
\hline
\end{tabular}

Table 9: Forecast Error Variance Decomposition of LNGDP (LNPL)

\begin{tabular}{ccccccc}
\hline Period & S.E. & LNGDP & LNPL & LNLF & LNHK & LNK \\
\hline 1 & 0.095 & 100.000 & 0.000 & 0.000 & 0.000 & 0.000 \\
2 & 0.128 & 91.354 & 6.324 & 0.846 & 0.624 & 0.852 \\
3 & 0.147 & 79.229 & 5.020 & 7.649 & 1.864 & 6.237 \\
4 & 0.158 & 71.134 & 5.048 & 12.270 & 2.505 & 9.043 \\
5 & 0.163 & 66.557 & 5.941 & 15.189 & 2.569 & 9.744 \\
6 & 0.167 & 64.458 & 6.689 & 16.766 & 2.489 & 9.597 \\
7 & 0.168 & 63.169 & 7.113 & 17.476 & 2.818 & 9.425 \\
8 & 0.170 & 61.783 & 7.093 & 17.582 & 4.058 & 9.484 \\
9 & 0.172 & 59.918 & 6.878 & 17.323 & 6.212 & 9.668 \\
10 & 0.176 & 57.822 & 6.694 & 16.908 & 8.763 & 9.817 \\
11 & 0.179 & 55.928 & 6.598 & 16.509 & 11.114 & 9.850 \\
12 & 0.182 & 54.486 & 6.548 & 16.215 & 12.944 & 9.806 \\
\hline
\end{tabular}

\section{Conclusion}

The central focus of this study is to analyze the impact of external debt on Malaysia's economic growth. This paper also examined the structure, magnitude and composition of Malaysia's external debt. As mentioned earlier the causes of external debt in Malaysia can be attributed to both internal and external factors; which include deterioration of terms of trade leading to balance of payment deficits, high world interest rate and increased protectionism by developed countries.

A vector autoregression (VAR) analysis is used to estimate and to evaluate the effect of external debts on economic growth. Specifically, the analysis is conducted both at aggregate and disaggregate levels in which for disaggregate analysis the total debt is decomposed into market and project loans. Results obtained indicate the existence of a long run cointegration relationship among variables. The aggregate estimation yields a much higher estimation and shows a correct sign of the coefficient of external debts. Using an error correction model, the estimation results confirm the existence of a long-term growth-debt cointegration relationship and that short-run is driven by the extent of the gap between current and long run equilibrium value.

Impulse response analysis provides a significant short-term dynamic interaction between GDP and independent variables. Meanwhile the estimations of variance decomposition indicate that in the short run the debt transitory shock plays a minor role as a driving force of economic growth in Malaysia. As for the total external debt the shock can significantly explain 2.2 percent of fluctuation in growth, after one year; as for market loans and project loans the shocks can explain only 0.96 percent and 6.32 percent respectively. 
From the results it is evident that external debt has an impact on Malaysia's economic growth, a onepercentage point will lead to an increase of GDP by RM1.29 million. It is also reveal that Malaysia does not has a debt overhang problem which creates adverse incentive effects on the economic growth in the long-run. Specifically the debt overhang problem stated that debts do not only affect investment in physical capital but also affect activities that involves incurring costs up-front for the sake of increased output in the future; i.e. investment in human capital and technology acquisition. Prudent debt management remains an integral thrust of fiscal policy in Malaysia. Effective policies and an efficient debt monitoring system ensure that the debt level is contained at a manageable level. Malaysia has adopted various financing strategies to diversify its external debt profile by achieving cost saving method and lengthening the maturity profile of the nation's debt; diversifying borrowings is one of the strategies. Heavy reliance on US dollar dominated loans, bringing about a situation whereby 93 percent of the market loans are made up of US dollar loans. No new external borrowing was raised in 2006, other than the disbursement of existing project loans to achieve the objective of reducing external debt and minimize exposure to external risks (see Economic Report, 2006/2007). The external borrowing that have been drawn down from bilateral and multilateral sources are used to finance ongoing projects, primarily for education and training, upgrading and rehabilitation of water supply, poverty eradication and ICT venture capital.

\section{REFERENCES}

1. Afxentoiu, P.C. and Serletis, A. (1996). Growth And Foreign Indebtedness In Developing Countries: An Empirical Study Using Long -Term Cross-Country Data. The Journal of Developing Areas, 31 (Fall), 2540.

2. _ (1966a). Foreign Indebtedness In Low And Middle Income Developing Countries. Social and Economic Studies, 45(1), 133-159.

3. Arize, A.C., Malindretos, J. and Christoffersen, S., (2003), Monetary Dynamics, Exchange Rates and Parameter Instability: An Empirical Investigation, Journal of Economics Studies, 30(5), 493-513.

4. Bauerfreund, O. (1989). External Debt And Economic Growth: A Computable General Equilibrium Case Study Of Turkey 1985-1986, Duke University, Ph.D.

5. Borenzstein, E. (1990). Debt Overhang, Credit Rationing And Investment. Journal of Development Economics, 32, 315-335.

6. Cunningham, R.T (1993). The Effect Of Debt Burden And Economic Growth In Heavily Indebted Nations. Journal of Economic Development, 18 (1), June 115-126.

7. Engel, R.F and Granger C. W. J. (1987). Cointegration And Error Correction: Representation, Estimation And Testing. Econometrica, 55, 251-276.

8. Ersoy, A. (1989). Liberal Economic Strategy For Debt Crisis Management: The Case Of Turkey In Singer, H.W. and Sharma, S., ed, Growth and External Debt Management. Macmillan

9. Faini, R. and DeMelo, J. (1990). Adjustment, Investment And The Real Exchange Rate In Developing Countries. Economic Policy 11, 491-519.

10. Feder, G. (1982). On Export And Economic Growth. Journal of Development Economics, 12, 59-73

11. Fosu, A.K. (1999). The External Debt Burden And Economic Growth In The 1980s: Evidence From SubSaharan Africa. Canadian Journal of Development Studies, 20 (2) 307-318.

12. Geiger, L.T. (1990). Debt And Economic Development In Latin America. The Journal Of Developing Areas, 24, 181-194.

13. Ghatak, S., Milner, C. and Utkulu, U. (1994). Trade Liberalisation And Endogenous Growth: Some Evidence For Turkey. Discussion Paper In Economics, University Of Leicester.

14. Gujarati, D. N. (1995). Basic Econometrics. $3^{\text {rd }}$ Ed. McGraw-Hill International Editions.

15. Hall.S.G. (1989). Maximum Likelihood Estimation Vectors: An Example Of The Johansen Procedure. Oxford Bulletin of Economics and Statistics, 51, 2.

16. Heilbroner and Bernstein (1989). The Debt and the Deficit: False Alarms/Real Possibilities, New York: W.W. Norton \& Company

17. Johansen, S (1988). Statistical Analysis Of Cointegartion Vectors. Journal of Economic Dynamics and Control, 12, (2/3), 231-254.

18. Krueger, A. O. (1987). Origins of the Developing Countries' debt crisis. Journal of Development Economics, 27,165-187. 
19. Maddala, G. S. (1988). Introduction to Econometrics. Mcmillan Publishing Companay, New York.

20. Metwally, M. M. and Tamaschke, R (1994). The Interaction Among Foreign Debt, Capital Flows and Growth: Case Studies. Journal of Policy Modeling, 16 (6) 597-608.

21. Romer, D.(1996). Advanced Macroeconomics. McGraw-Hill Companies, Inc., New York.

22. Savvides, A. (1992). Investment Slowdown in Developing Countries during the 1980s: Debt Overhang or Capital Foreign Inflows. Kyklos, 45 (3), 363-378.

23. Solow, R. (1956). A Contribution to the Theory of Economic Growth. Quarterly Journal of Economics, 70, 65-95.

\section{NOTES}

